\title{
Selection of Streamflow and Reservoir-Release Models for River-Quality Assessment
}

River-Quality Assessment of the Willamette River Basin, Oregon

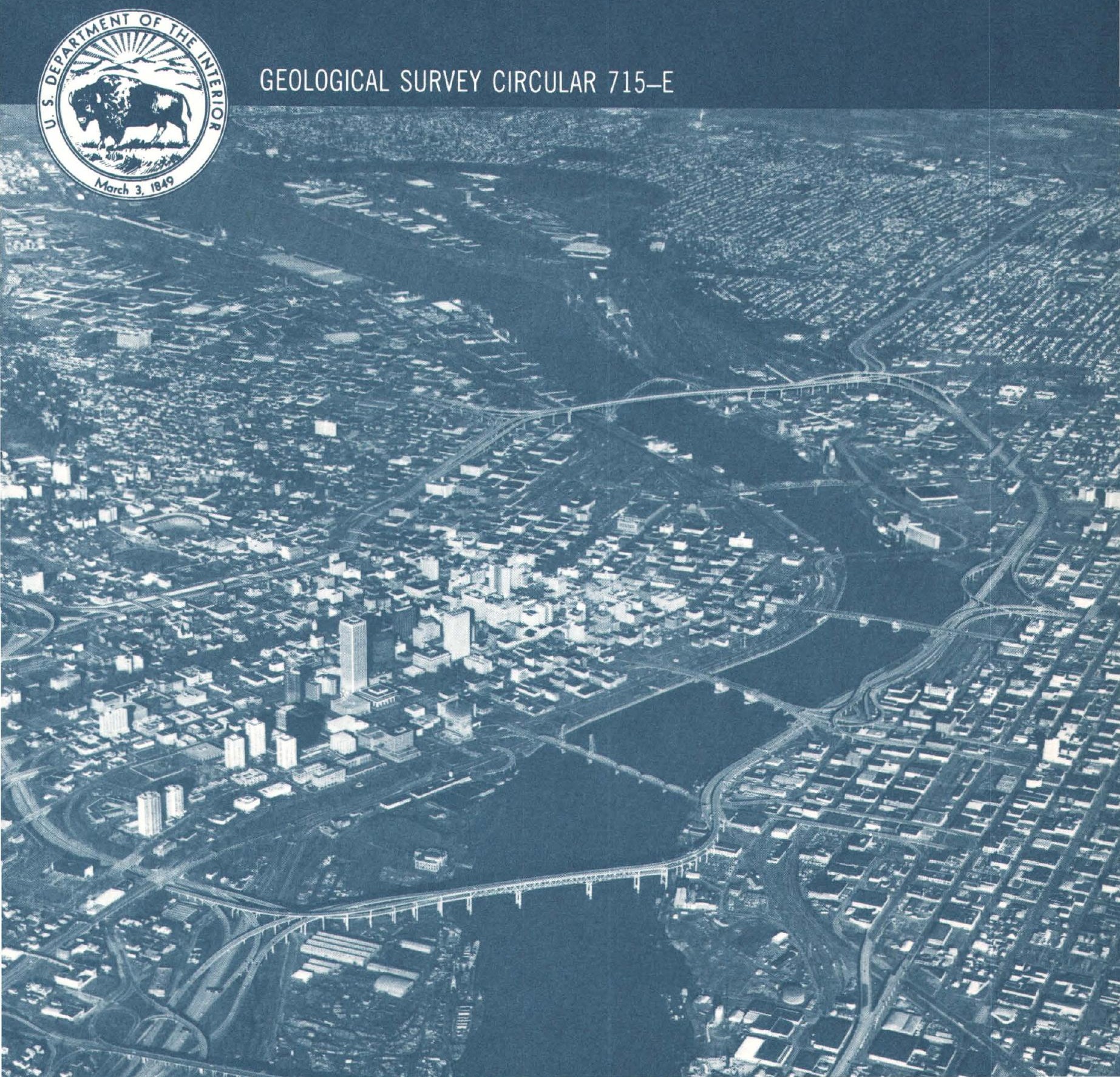





\section{Selection of Streamflow and Reservoir-Release Models for River-Quality Assessment}

By Marshall E. Jennings, James O. Shearman, and Daniel P. Baver

RIVER-QUALITY ASSESSMENT OF THE WILLAMETTE RIVER BASIN, OREGON

GEOLOGICAL SURVEY CIRCULAR715-E 


\section{United States Department of the Interior}

THOMAS S. KLEPPE, Secretary

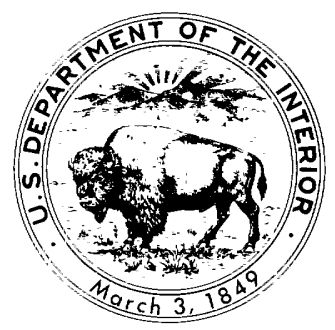

Geological Survey

V. E. McKelvey, Director

Library of Congress Cataloging in Publication Data

Jennings, Marshall E.

Selection of streamflow and reservoir-release models for river-quality assessment. (River-quality assessment of the Willamette River Basin, Oregon)

(U.S. Geological Survey Circular 715-E)

Bibliography: p. 12.

Supt. of Docs. no.: I19.4/2:715-E

1. Stream measurements-Mathematical models. 2. Stream measurements-Data processing.

3. Reservoirs-Mathematical models. 4. Reservoirs-Data processing. 5. Willamette

River watershed. I. Shearman, James O., joint author. II. Bauer, Daniel P., 1941-

joint author. III. Title. IV. Series. V. Series: United States Geological Survey Circular 715-E.

QE75.C5 no. 715-E[GB1201.72.M35] 557.3'08s [627'.86'097953] 76-608240 


\section{FOREWORD}

The American public has identified the enhancement and protection of river quality as an important national goal, and recent laws have given this commitment considerable force. As a consequence, a considerable investment has been made in the past few years to improve the quality of the Nation's rivers. Further improvements will require substantial expenditures and the consumption of large amounts of energy. For these reasons, it is important that alternative plans for river-quality management be scientifically assessed in terms of their relative ability to produce environmental benefits. To aid this endeavor, this circular series presents a case history of an intensive river-quality assessment in the Willamette River basin, Oregon.

The series examines approaches to and results of critical aspects of riverquality assessment. The first several circulars describe approaches for providing technically sound, timely information for river-basin planning and management. Specific topics include practical approaches to mathematical modeling, analysis of river hydrology, analysis of earth resources-river quality relations, and development of data-collection programs for assessing specific problems. The later circulars describe the application of approaches to existing or potential river-quality problems in the Willamette River basin. Specific topics include maintenance of high-level dissolved oxygen in the river, effects of reservoir release patterns on downstream river quality, algal growth potential, distribution of toxic metals, and the significance of erosion potential to proposed future land and water uses.

Each circular is the product of a study devoted to developing resource information for general use. The circulars are written to be informative and useful to informed laymen, resource planners, and resource scientists. This design stems from the recognition that the ultimate success of river-quality assessment depends on the clarity and utility of approaches and results as well as their basic scientific validity.

Individual circulars will be published in an alphabetical sequence in the Geological Survey Circular 715 series entitled "River-Quality Assessment of the Willamette River Basin, Oregon."

J. S. Cragwall, Jr.

Chief Hydrologist 
Cover: Willamette River as it winds through Portland, Oregon. Photograph taken by Hugh Ackroyd. 


\section{CONTENTS}

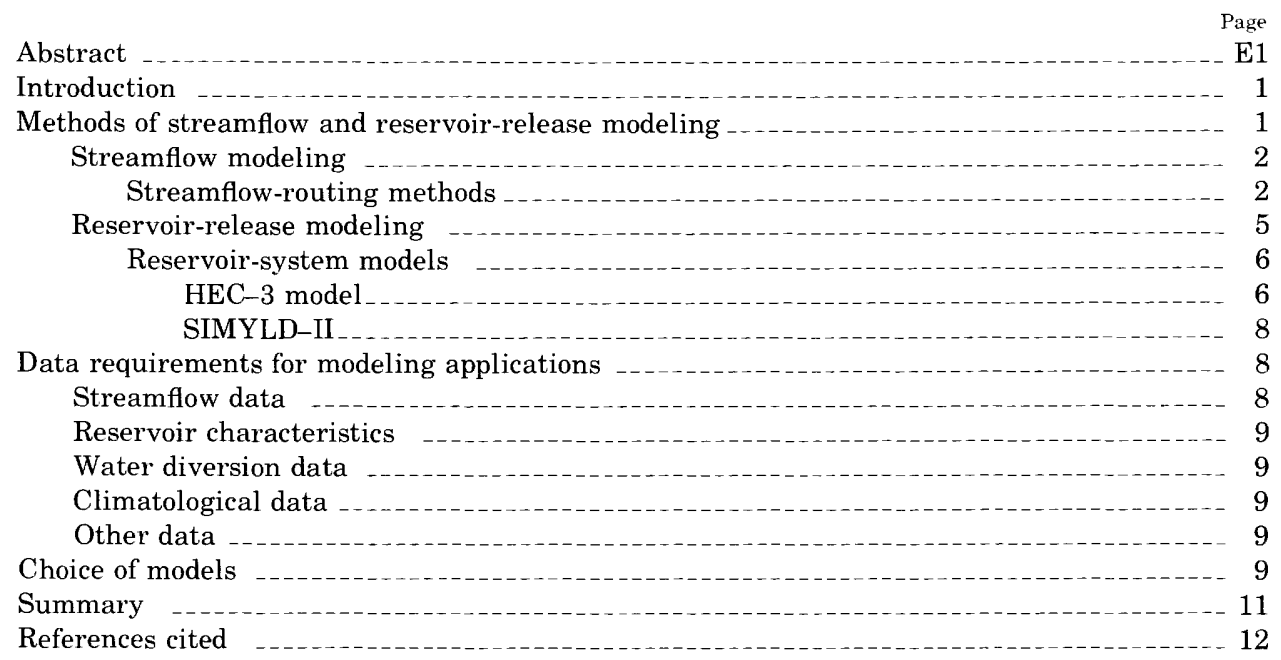

\section{ILLUSTRATIONS}

FIGURE 1. Graph showing simple streamflow routing problem

2. Map showing complex streamflow routing problem, upper Kentucky River basin

3. Graph showing typical rule curve for reservoir operation and its relation to computer program HEC-3 --.. 7

4. Diagram showing model selection process

\section{TABLE}





\title{
SELECTION OF STREAMFLOW AND RESERVOIR-RELEASE MODELS FOR RIVER-QUALITY ASSESSMENT
}

\author{
By Marshall E. Jennings, James O. Shearman, and Daniel P. Baver
}

ABSTRACT

Sound water-resource planning requires consideration of realistic alternatives. Digital models, based on hydraulic and hydrologic principles and utilizing adequate input data, can be used to simulate the responsets I of a water-resource system to various alternatives. Streamflow and reservoir modeling methods are reviewed, including a discussion of general data requirements. Guidelines for model selection are presented with both hypothetical and actual studies used to illustrate possible selection procedures.

\section{INTRODUCTION}

During the last century there has been a steadily increasing need for water and water-oriented services. To satisfy these needs, rapid technological advancement is being made to develop the necessary tools for water-resource planning. These tools, or models, must be effectively applied for the timely solution of planning problems connected with increasing development of water resources at the local, regional, and national levels. During the next 30 years, the National Water Commission (1973) predicts that the Nation will decide a number of key issues of water policy. Good planning, the Commission states, should be based on a range of realistic "alternative futures" and should set forth alternative courses of action to promote flexible responses. Planning of this kind underscores the need for water-resource models, based on hydrologic principles, data, and related information. Well-verified hydrologic models are capable of simulating response(s) to "alternative futures" to provide information for effective decision making.

The Willamette River basin was the first basin in which the U.S. Geological Survey conducted an intensive river-quality assessment study. As explained by Rickert and Hines (1975), one objective of that study was to develop and document methods for evaluating basin-development alternatives in terms of potential impacts on river quality. One major need of such a study is the capability to simulate future streamflow and reservoir releases in the river system. Successful development of this capability depends greatly upon choosing the most appropriate model(s). To provide an overview of successful model selection, this paper (1) reviews the general types of existing models for simulating streamflow and reservoir releases and (2) provides guidelines for model selection for a range of study requirements. The Willamette River basin study is cited only as one specific example of model selection. A complete discussion of the Willamette River basin reservoir-system model will be presented in a subsequent report in this series (Shearman, 1976).

\section{METHODS OF STREAMFLOW AND RESERVOIR-RELEASE MODELING}

Streamflow modeling and reservoir-release modeling are fundamental building blocks in modeling surface-water systems. General types of models will be reviewed here to familiarize the reader with specific flow-modeling concepts applicable to river-quality assessment studies. The emphasis in this review is on flow modelswater-quality models are discussed and used for analyses in other circulars of this serjes.

Streamflow and reservoir-release models are basically deterministic in character, as opposed to statistical or stochastic. Deterministic models, because they offer a better definition of cause and effect relationships, have greater value as waterresource planning tools. They range considerably in complexity and level of mathematical sophistication. For example, some of the most complex 
models rely on numerical solution of the basic hydraulic equations of flow-the conservation of mass and momentum equations-which arise from basic physical laws. On the other extreme, some of the simpler hydrologic models utilize a "black-box" approach and make minimal attempt to recognize and model real-world phenomena in a "structure-imitating" way. A "black-box" model attempts to reproduce observed system outputs using observed system inputs and a simple function, usually linear, which characterizes the unknown physical system. An example of "blackbox" modeling in hydrology is a simple linear regression model which relates basin runoff (system output) to basin rainfall (system input) using monthly values. There is much diversity of opinion as to whether highly sophisticated, numerical models of explicit physical laws or simpler "hydrologic" models is the better approach. A modeler who is completely enthralled by the divine power of mathematics might insist that the former is the only valid approach. The other extremist, who feels that the end result justifies any means, may insist upon using the simplest "black-box" model regardless of its physical insignificance. A sensible modeler will arrive at a reasonable choice of a model that lies somewhere between these two extremes by balancing recognizable data limitations with (1) relative costs and problems associated with increasingly complex models and (2) the high improbability of achieving full realism with any model. The problem situation should dictate the modeling approach with a proper choice tempered by adherence to Occam's Maxim. ${ }^{1}$ Data requirements, discussed below, are a definite factor in model selection. Another important factor is the time scale of events-whether a monthly time interval model is satisfactory or whether hourly analysis is required.

\section{STREAMFLOW MODELING}

Streamflow modeling embraces the quantitative description of surface flow in rivers, canals, and estuaries. The objective of streamflow modeling is to simulate streamflow at any location in a river basin where such data are required to satisfy a need. This simulation is usually accomplished by using streamflow-routing methods.

\footnotetext{
${ }^{1 " E n t i t i e s ~ a r e ~ n o t ~ t o ~ b e ~ m u l t i p l i e d ~ w i t h o u t ~ n e c e s s i t y " ~ o r ~ " I t ~ i s ~ v a i n ~ t o ~ d o ~ w i t h ~}$ more what can be done with fewer," due to William of Occam (ca 1300), a western philosopher
}

Streamflow routing involves calculation of flow-rate hydrographs (and sometimes river stage) in a river channel system in response to streamflow data inputs. The routing may involve low flows, high flows, and mid-range flows on a continuous basis for a given time interval (days, months, or years). Most water-resource planning problems require simulation for as long a period as data will allow, in order to facilitate statistical analysis of results and calculation of flowrecurrence probability.

The simplest streamflow-routing problem involves routing of flow-rate hydrographs from an upstream to a downstream point in the channel. Figure 1 schematically illustrates a very simple situation.

Computation of the flow-rate hydrograph at the downstream point could conceivably range from (1) a simple multiplication of the upstream flowrate hydrograph by a constant drainage-area ratio to (2) the solution of a complex set of mathematical equations describing the system. Figure 2 shows the problem setup for a water-resource planning problem in the upper Kentucky River basin in southeastern Kentucky as reported by Shearman and Swisshelm (1973). Tro latter is much more typical of the problems antually encountered in water-resource planning. Daily flows were simulated for a 31 -year period using 4 basic streamflow-routing reaches, 10 long-term daily streamflow records, and a linear streamflow-routing method.

There are three basic categories of streamflowrouting methods or models: (1) Models based on numerical solution of complete or simplified versions of the hydraulic laws of flow-the continuity and momentum equations; (2) models based on the linear systems approach using convolution solution techniques; and (3) empirical models. As listed, the categories of streamflow-routing models are in decreasing mathematical and computational complexity. Over the last 30 years, research has produced dozens of streamflow-routing models in each category. Most have produced excellent to acceptable results in the particular situations for which they were developed.

The numerical solution of basic hydraulic equations by finite-difference of finite-element methods represents the most ccmplex of streamflow-routing models. These partial differ- 

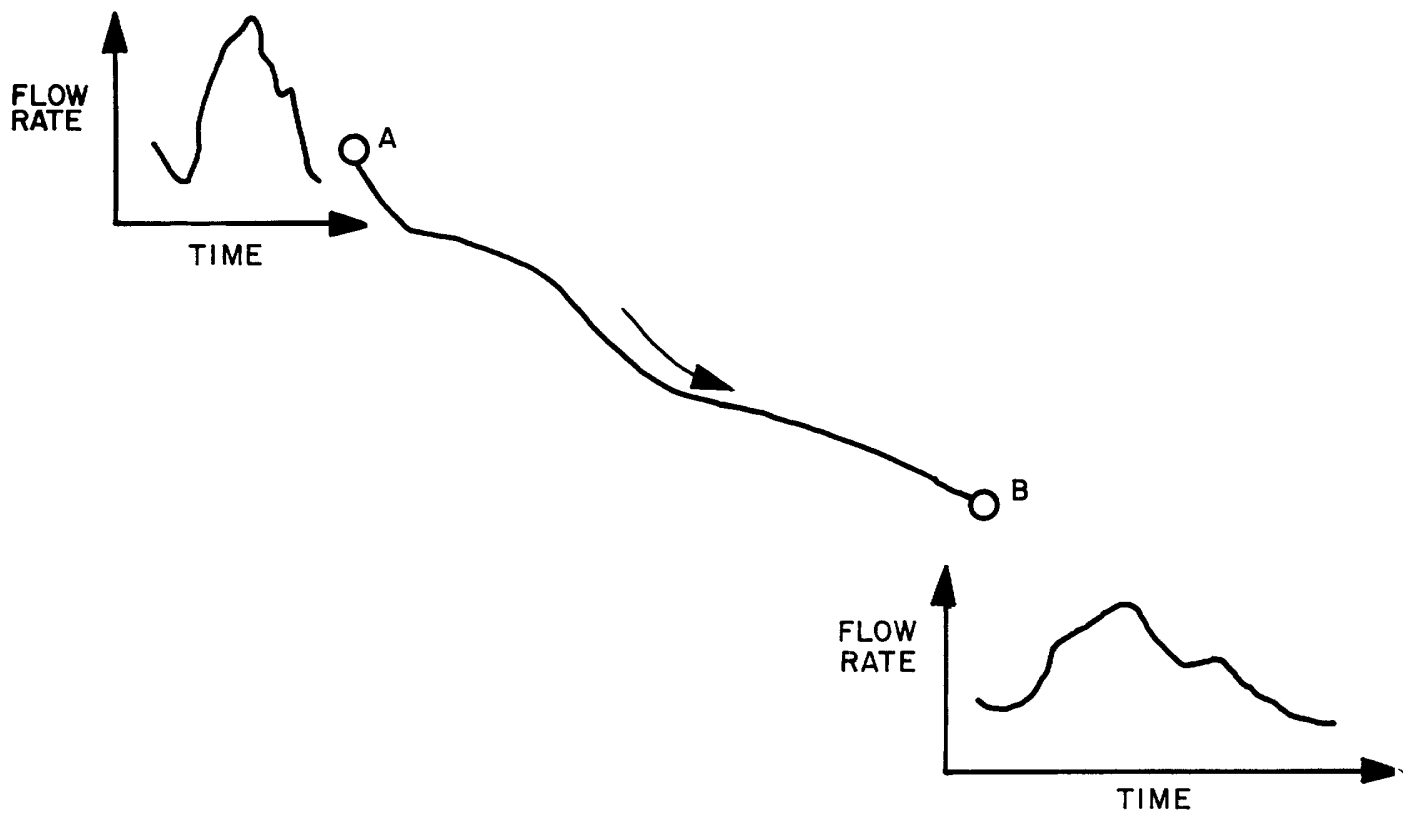

FIgURE 1.-Simple streamflow routing problem.

EXPLANATION

PLANNED OR

EXISTING RESERVOIRS

- USGS STREAMGAGING STATIONS

AND

$\int$ STREAM FLOW

ROUTING POINTS

DIRECTION OF FLOW

BASIN BOUNDARY

FIGURE 2.-Complex streamflow-routing problem, Upper Kentucky River basin. 
ential equations in one-dimensional form from Fread (1974) are:

$$
\begin{array}{r}
\frac{\partial A}{\partial t}+\frac{\partial(A V)}{\partial x}-q=0 \quad \text { Conservation of mass } \\
\frac{\partial V}{\partial t}+\frac{1}{2} \frac{\partial V^{2}}{\partial x}+g\left(\frac{\partial H}{\partial x}-S_{0}+\frac{\bar{n}^{2}|V| V}{2.21 R^{4 / 3}}\right) \\
+\left(V-V_{q x}\right) \frac{q}{A}=0 \quad \begin{array}{c}
\text { Conservation of } \\
\text { momentum }
\end{array}
\end{array}
$$

where

$x=$ the distance along the river axis, positive in the downstream direction;

$$
t=\text { time; }
$$

$A=$ wetted cross-sectional area;

$V=$ mean velocity in a cross section;

$H=$ depth of flow in a cross section;

$S_{0}=$ channel bottom slope;

$q \quad=$ lateral inflow per unit length along the river axis;

$V_{q x}=$ mean velocity of lateral inflow in the $x$-direction;

$R=$ the hydraulic radius;

$\bar{n} \quad=$ Manning's roughness coefficient; and

$g \quad=$ acceleration due to gravity.

Equation 1a describes the mass balance of fluid volumes that must exist within a volume of moving incompressible fluid. Equation $1 b$ represents a mass balance of forces including those forces due to acceleration, potential energy, and friction which must be conserved according to basic physical laws, within a volume of moving fluid. Interested readers are referred to well-known texts in fluid hydraulics such as Henderson (1966). Models based on these equations have a large data requirement, are computationally expensive, are difficult for inexperienced hydrologists to apply, have a tendency for numerical instability problems, and therefore, may be unsuitable for long-term simulation. Nevertheless, these models are an attempt at superior realism and must be used sometimes to solve problems of detailed hydraulic interest, especially those characterized by flow unsteadiness. Recent advances in the field of numerical streamflow routing include the work of Amein and Fang (1970), Baltzer and Lai (1968), Contractor and Wiggert (1972), Fread (1974), Garrison, Granju, and Price (1969), and U.S. Army Corps of Engineers (1973a). Computer programs with documentation are available for many models of this type.

Streamflow-routing models based on a linear systems approach can be summarized in the convolution integral (Schwarz and Friedland, 1965),

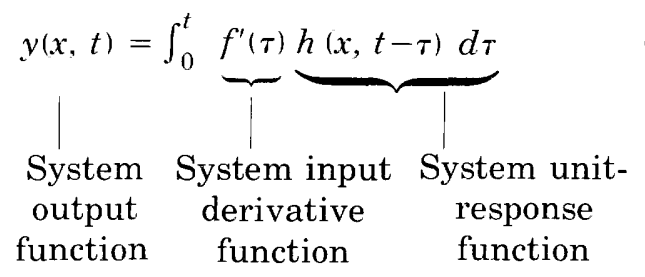

In equation 2, which is used in discrete form in actual computation, $\tau$ is the variable of integration. The convolution integral of equation 2 represents the integration, on a time-varying basis, of a system input function (for example, an upstream flow hydrograph) and the system unitresponse function, to produce the system output function (for example, a downstream flow hydrograph). The system unit-response furction represents the system output for an instantaneous unit input. This type of modeling exhibits the following advantages: (1) Linearized solutions of the hydraulic equations are an adequate description of the flow process for most streamflow-routing problems; (2) linear systems models. employing the convolution technique, are easily programmed, are numerically stable, and are computationally inexpensive; (3) many older linear techniques, such as Muskingum routing, can be incorporated as options in a basic linear systems computer program; and (4) as much detail as deemed necessary, in terms of hydraulics, can be incorporated into the system unit-response function [that is, the unit-response function can be simple, as in the Sauer model (Sauer, 1973), or the function can be fairly complicated as in the Harley model (Harley, 1967)]. Thus, linear systems models are ideal for long-term simulations required in many water-resource planning studies. Some linear systems streamflow-routing models of use in water-resource planning studies are those by Sauer (1973), Keefer and McQuivey (1974), Hayami (1951), Harley (1967), and Moench, Sauer, and Jennings (1974). The Keefer and McQuivey model utilizes a family of unitresponse functions and appears to be especially suited for studies which require data input at short (for example, hourly) time intervals. The Moench model incorporates stream losses and 
gains attributable to interaction with the ground-water system into a streamflow-routing model.

Empirical streamflow-routing models include statistical methods, successive moving average methods, and simple-lag methods. Several methods of this type are discussed in Linsley, Kohler, and Paulhus (1949).

Reverse routing (that is, routing in an upstream direction) is a special case of streamflow routing. This type of model is often required in water-resource planning studies where an existing downstream gaging record must be moved to an upstream computation point. Examples of reverse routing using a numerical model are found in Eli, Wiggert, and Contractor (1974). A reverse-routing method using a linear-systems model was employed by Shearman and Swisshelm (1973).

Noteworthy among available computer programming packages for streamflow routing, not necessarily adapted to simulation, are: (1) the HEC-1 package (U.S. Army Corps of Engineers, $1973 \mathrm{~b})$; (2) the Tennessee Valley Authority package (Garrison and others, 1969); (3) the Agricultural Research program, HYMO (Williams and Hann, 1973); and (4) the SSARR model (Anderson, 1969). A generalized streamflow-modeling package is under development by Shearman (written commun., 1976).

\section{RESERVOIR-RELEASE MODELING}

In addition to being important in itself, the quality and quantity of water stored in reservoirs is important in controlling downstream river quality. Reservoir-release modeling includes simulating the operation of single reservoirs, reservoir systems, and water diversions and transfers. Losses of water from reservoir units and systems are included in this type of modeling.

Reservoirs are located in stream channels for various purposes including flood control, water supply, irrigation, recreation, navigation, lowflow augmentation for water-quality or habitat enhancement, and electric power generation. A broad classification of reservoirs is based on the design purpose of the reservoir as follows: (1) Single purpose-a reservoir designed for only one of the above mentioned purposes; (2) multipurpose-a reservoir designed for more than one of the purposes listed above; and ( 3 ) reservoir system-two or more single and (or) mul- tipurpose reservoirs designed to operate interactively. Understanding the purposes of a reservoir system and other flow regulation operations is fundamental to reservoir-release modeling.

Several Federal agencies design and construct reservoirs. Most notable among these are the U.S. Army Corps of Engineers, the U.S. Bureau of Reclamation, and the Tennessee Valley Authority. State agencies are becoming more active in reservoir regulation studies as the result of the recent trend towards State water-resource planning. Reservoir regulation schedules, for existing and proposed reservoirs for all reservoir purposes, are generally available from such agencies. These are necessary for realistic reservoir-release modeling and generally form the basis for initial assessments aimed at water-resource planning. However, in many cases, departures from preset regulation schedules, either in simulation or in actual operation, may be necessary and desircble.

The mass-balance model of equation 3 is the basic type of reservoir release model,

$V O L_{t}=V O L_{t-1}+\Sigma I_{t}-\Sigma 0_{t}+P_{t}-E_{t}$

where

$$
\begin{aligned}
& V O L_{t}, V O L_{t-1}=\text { reservoir volumes at times } \\
& t \text { and } t-1 \text {; } \\
& \Sigma I_{t} \quad=\text { summation of ell inflow }
\end{aligned}
$$

In the simplest case, the Puls solution method (Henderson, 1966) or some modification is used. More complicated methods for sloping reservoir surfaces, complex gage operation, or downstream control are sometimes necessary. Methots of flood control operation are given in Beard (1963). General reservoir-modeling techniques are found in U.S. Army Corps of Engineers (1969). A general review of reservoir-modeling methods is given in Rutter and Engstrom (1964). The previously cited 
study by Shearman and Swisshelm (1973) is an example of reservoir-release modeling for waterresource planning involving a fairly simple multipurpose reservoir.

In addition to definition of the hydraulics and hydrology of reservoirs or reservoir systems, the solution of reservoir operation problems relies on either simulation or mathematical programming techniques to arrive at optimal operating policy under multiobjective criteria.

In the simulation approach, the effects of an operating rule are simulated on the basis of a sequence of streamflows-either a historical sequence if length of record is sufficient, or a synthetic sequence using methods of synthetic streamflow generation described by Fiering and Jackson (1971). Trial and error or search procedures are used to find the best operating rule.

Methodologies for reservoir or reservoir-system optimization include the specialized tools of mathematical programming, dynamic and linear programming, including combinations of these methods with stochastic or deterministic constraints. The methods involve solution for storage or outflow variables if a system of mass balance equations similar to equation 3 describe the balance of water volumes in a more complex reservoir system. Hall and Dracup (1970) and Hufschmidt and Fiering (1966) have reviewed the important methods related to water-resources systems engineering. Some recent applications of these methods include those by Becker and Yeh (1974) and Roefs and Bodin (1970).

\section{RESERVOIR-SISTEM MODELS}

Recently, many existing or planned reservoir projects have been viewed, designed, or redesigned as reservoir systems. Analyses of such systems can be extremely complex and require the use of special computer programming techniques and analysis. Two important computer programs for reservoir systems analysis are reviewed here-the U.S. Army Corps of Engineers (1968) HEC-3 program, based on a simulation and search procedure, and the Texas Water Development Board (1972) program SIMYLD II, based on a linear programming procedure.

$$
\text { HEC-3 MODEL }
$$

This computer program was developed by the Corps of Engineers to perform multipurpose, mul- tireservoir routings in a reservoir system. The model is capable of providing a variety of information about the response(s) througl sut a reservoir system when given the system input(s) and the system constraint(s).

HEC-3 is capable of analyzing almost any reservoir-system configuration imaginable and is fully documented (U.S. Army Corps of Engineers, 1968). System configuration is described to the model by means of control points at reservoirs, diversion points, and stream confluerses. At each control point, the mass balance may be computed for the portion of the system contributing flow to that point. System size and record length for analysis is limited primarily by available computer core storage. Either uniform or varying time periods may be used, with a present limit of 14 time periods per year.

Input data requirements for the model are extensive. At each control point, the total "natural" inflow rates for each time period must be provided for each year of analysis. Minimum and maximum flows also may be specified for each control point. At each diversion point, the diversion rates (or return flow rates) must be specified for each time period. Evaporation rates must be specified for each time period on a yearly basis. Each reservoir in the system must be described in terms of its elevation-area-storage-outlet capacity relationships and its operating rules. TJp to eight "storage levels" may be specified for each time period to define the operating rules for each reservoir (see fig. 3). Reservoir releases are computed throughout the system such that all reservoirs are operating at the same relative "storage level" during each time period. For example: during a given time period during a relatively wet year, all reservoirs may be operating in the seventh "storage level", whereas in a very dry year all reservoirs may be depleted to the fourth "storage level" for the same time period such that all desired flows are satisfied. Not only does this permit interactive operation of all reservoirs, but storage at one reservoir may be depleted more rapidly than the others by assigning a greater percentage of its storage to the higher levels. Each hydropower plant is described in terms of its elevation-capacity efficiency relationships and power requirements. Provisions are available to permit changes in system operation or demands at the end of specified years.

An iterative procedure is used to maintain 


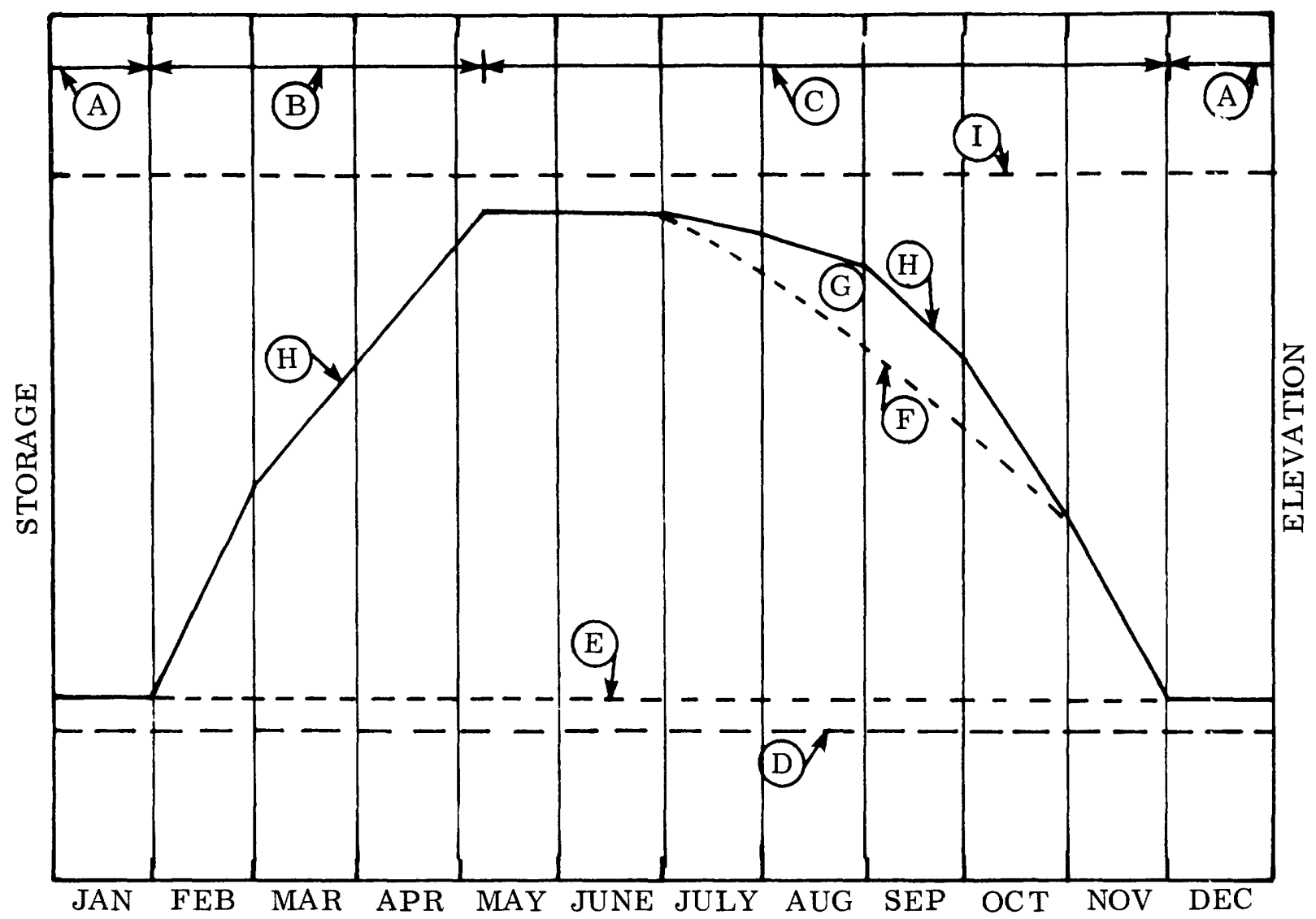

A Major Flood Period--reservoir held to minimum elevation (storage) for flood control.

(B) Conservation Storing Period-- reservoir filled for conservation purposes.

(C) Conservation Release Period--stored water released as needed.

(D) Minimum Reservoir Elevation (Storage)--minimum "storage level" specified for HEC-3.

(E) Top of Power Storage--next to lowest "storage level" specified for HEC-3.

(F) Bottom of flood control pool for "dry conditions" (whereas $\mathrm{H}$ represents "ideal", "normal", or "average" conditions.)

(G) Intermediate "storage levels" may be used to control the rate of depletion below "ideal" for various degrees of "belowaverage" conditions, and among reservoirs in the system.

(H) Bottom of Flood Control Pool--next to highest "storage level" specified for HEC-3.

(I) Maximum Reservoir Elevation (Storage)--maximum "storage level" specified for HEC-3.

FIGURE 3.-Typical rule curve for reservoir operation and its relation to computer program HEC-3. 
storage balances and required flows throughout the system. Initially, reservoir releases are computed such that all flow, power, and diversion requirements are satisfied. These releases, combined with evaporation losses, may result in storage imbalances in the system. If so, releases are adjusted for storage balancing and, if necessary, shortages may be declared for specified power, flow, and (or) diversion requirements.

Model results may be output for every time period or limited to yearly output or simply final results. Various summaries may be obtained for natural and regulated streamflows, reservoir data, and shortage information. Summaries may be obtained for all years at each control point, or all control points for each year.

In general, HEC-3 is a very useable tool. However, computational costs can be somewhat high (especially on a computer system with fairly high input/output charges) and input data coding is fairly complex.

\section{SIMILD II}

SIMYLD II is a computer program designed to simulate, on a monthly basis, the hydrologic operation of a system of interconnected reservoirs within a basin or a multibasin water-resource system. The program was developed by the Texas Water Development Board, Austin, Tex., and is fully documented (Texas Water Development Board, 1972).

Given a specified sequence of demands and hydrologic conditions for a multireservoir waterresources system, SIMYLD II may be used to: (1) simulate the operation of the system, or (2) determine the maximum firm yield that can be met at a point within the system.

According to Tischler (1973), SIMYLD II is designed for extreme flexibility in selecting operating rules for each reservoir. The operating rules are formulated as the desired percentage of the reservoir capacity (either total or conservation capacity) to be held in storage at the end of each month. A priority ranking can be assigned to storage levels in each reservoir. This ranking is then used to determine the allocation of water between meeting demands and maintaining storage. The program user may, simply by changing the operating rules, vary the desired storage levels on a monthly basis and the priority of allocation of water between satisfying immediate demands and maintaining storage in the reser- voirs. Constant or time-variable demands and any selected hydrologic sequence-historical or synthetic_can be used to simulate the operation of the system.

Basic data requirements are essentially the same as for the HEC-3 program. Major exceptions are: (1) power-generating reservoirs are not considered; (2) only three "storage levels" (representing average, wet, and dry conditions relative to amount of available water) may bo specified to define operating rules; (3) the time periods must be calendar months; and (4) certain target flow requirements must be specified on a yearly basis rather than varied by time periods.

SIMYLD II adjusts reservoir content and stream reach discharges on a monthly basis to compute optimum values to meet the system demand considerations. Results include a time history of optimal operation including reservoir storages, water transfers and spills, demands met, and shortages incurred during the simulation period.

The program is easier to set up than HEC-3, fairly general in application, and relatively inexpensive to use. The program is limited somewhat by the exceptions listed above.

\section{DATA REQUIREMENTS FOR MODELING APPLICATIC NS}

Reliable data are a prerequisite for any waterresources planning activity, and the adequacy of the data greatly affects modeling accuracy and the applicability of modeling results. Types of data that are required for streamflow and reservoir-release modeling include: (1) streamflow, (2) reservoir characteristics, (3) water diversions and transfers, and (4) climatological effects.

\section{STREAMFLOW DATA}

Basic streamflow data, including daily flow values at several thousand gaging stations, are published yearly by the U.S. Geological Survey (for example, U.S. Geological Survey, 1973). Such information is also published on a project basis by the Corps of Engineers as well as by other Federal and State agencies. In recent years streamflow data have been placed on rapid-access computer storage devices for ease of use in water-planning studies (Showen and Stuthmann, 1973). Published streamflow data are not always directly applicable to river-quality assessment. Therefore, 
additional studies may be necessary to produce the unregulated streamflow data required for simulation studies. For most river-quality investigations, daily or monthly streamfiow data are sufficient.

\section{RESERVOIR CHARACTERISTICS}

Reservoir characteristics include system configuration, area-capacity curves, outlet capacity curves, power generation curves, and channel and diversion capacity. These data are available in engineering design and planning documents by agencies responsible for particular projects.

\section{WATER DIVERSION DATA}

Water diversion and transfer data are of significant importance for determining the total streamflow record and for scaling reservoir system demands. Unfortunately, such data are not always based on gaged records and must be estimated. For some studies, future diversion and other demands must also be estimated.

\section{CLIMATOLOGICAL DATA}

The most important climatologic factors that affect reservoir modeling are usually rainfall and evaporation. Such data are available from the National Weather Service, National Oceanic and Atmospheric Administration, and from project offices of construction agencies. Sometimes, particularly in the case of evaporation data, monthly estimates, used repetitively for each year of simulation, are the only data available.

\section{OTHER DATA}

Other data of a specialized nature may be required for some modeling purposes; for example, flow-range constraints, channel-capacity constraints, and minimum flows for fish habitats. Most reservoir-system models have control points where such information is required. In some cases, adequate time exists to undertake a shortterm data collection program to provide a minimum data base for planning studies. If adequate data are available, additional streamflow data may be simulated statistically (Fiering and Jackson, 1971) for use as system inputs. Synthetic streamflows may also be used to test system performance under equally likely, and perhaps more severe, hydrologic conditions.

\section{CHOICE OF MODELS}

Several choices are presented to the modeler who is required to furnish modeling results for use in river-quality planning studies. Following a definition of modeling objectives and acc uracy requirements, a thorough study of the existing and extractable data base must be made. Models should be selected and the data base restudied along with a review of modeling objectives. Figure 4, which might be called a "question-choice" diagram, shows the various choices which must be made. The questions are not listed in any particular order but, as a group, include the major ones confronting the modeler.

Questions which should be asked at the outset of the study include: Are streamflow and other data adequate to fulfill modeling objectives including results based on a long-term simulation? This objective requires continuous data at all important system input points. Are such data stored on computer for easy use or must it be keypunched from basic data reports? The availability of the data will have an impact on the time and cost of the overall study. Are the data reliable and appropriate for the study purpose? Is lack of factual climatological data a constraint? Should a short-term data base be started?

In considering model selection, additicnal questions to be considered are: Should a complex or a simple model be selected in view of study objectives and the data-base adequacy? Can the modeling results attain the necessary accuracy requirement? Does a computer program of the model already exist for use? Obviously, these are questions of critical importance. The time interval of available data is definitely related to modeling sophistication. Obviously the sophistication of a streamflow-routing model should not exceed data availability. Increased model complexity, if required by study objectives, should be tempered by review of staff ability and time and money costs. The question of whether an optimizaticn method based on mathematical programming or a simpler simulation method should be used for determining system operation is of importance.

There are no easy answers to the akove questions, nor are there ready guidelines for use in developing a correct modeling approach for riverquality studies. Each study will undoubtedly possess some unique objectives and data problems. Recognition of the major factors and choices is 


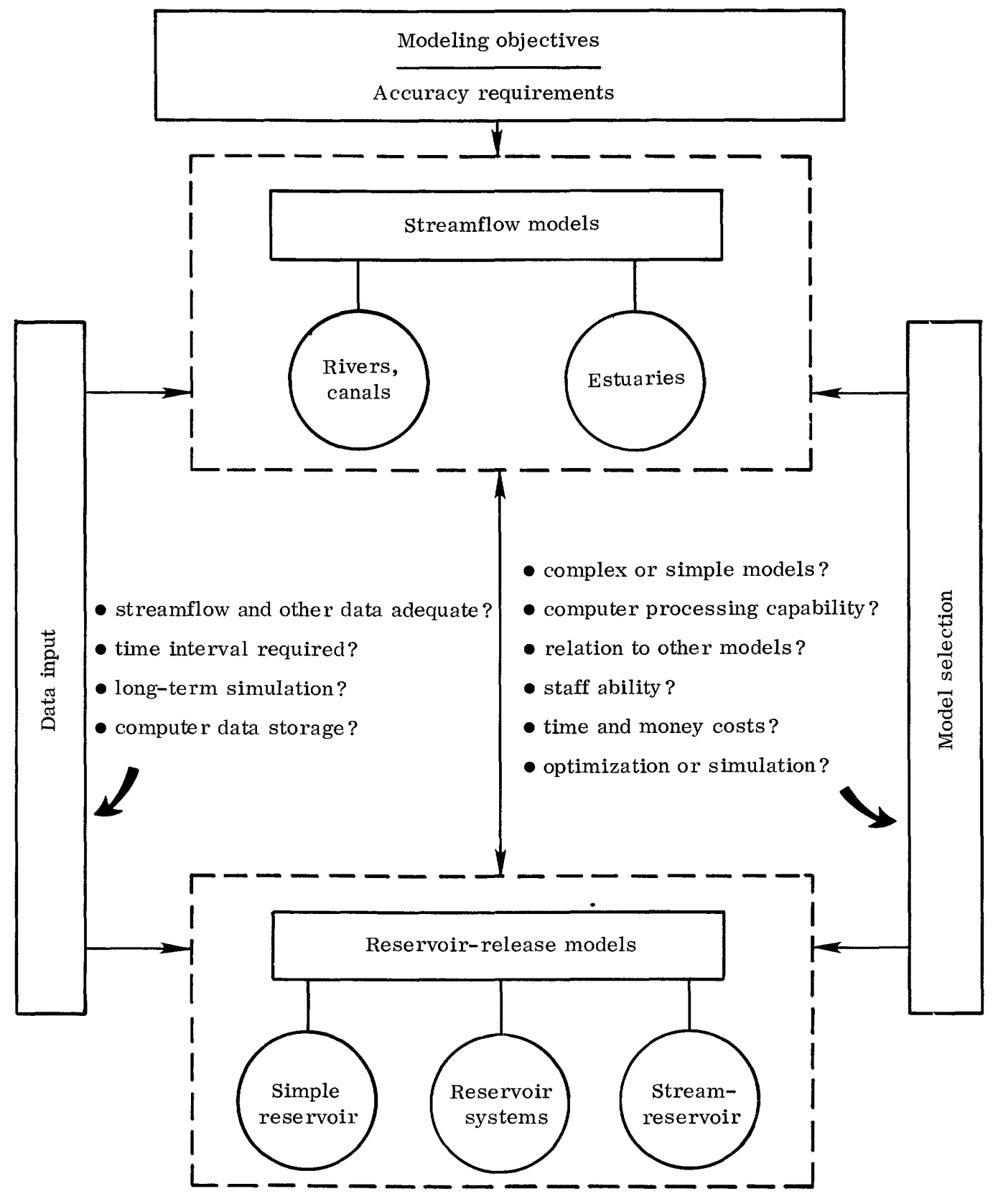

FigurE 4.-Model selection process by use of a question-choice diagram. 
important in arriving at cost-effective modeling decisions. These factors for many modeling studies are: (1) study requirements, (2) study resources, and (3) study choices. Shown in table 1 in generalized form are suggested categories of choices associated with each of the three factors. Table 1 expands upon the selection criteria introduced in figure 4. A table similar to table 1 but structured to the unique study situation is recommended as part of the study planning phase. Such a table would serve to focus attention on alternatives and aid in making correct study choices.

The objective of the "choice" process might be to keep the categories as consistent as possible. For example, suppose a hypothetical set of modeling study requirements are: (1) 20 percent error, (2) short-term study, (3) transient (daily) riverquality analysis, and (4) a single reservoir. The study resources are: (1) Research staff, (2) flexible funding, (3) available computer program extendably applicable, and (4 large-core digital computer available. Assuming table 1 applied to the hypothetical study, choices might follow as: (1) Accept the study, (2) choose rather complex streamflow and reservoir release models, (3) choose a daily modeling time interval, and (4) choose a simulation period of 1-5 years for hydrologic detail but no statistical comparisons.

As a further example, suppose modeling study requirements are: (1) 20 percent error, (2) moderate-term study, (3) steady-state river-quality analysis, and (4) reservoir-system configuration. Study resources include: (1) strong staffhydrologic modeling background, (2) flexible funding, (3) available computer programs extendably applicable, (4) large-core digital computer available, and (5) fair data availability and adequacy. A planning analysis similar to table 1 might lead to project choices as follows: (1) Accept the study, (2) choose complex modeling for reservoir-system analyses, (3) choose monthly time interval of modeling, and (4) choose 25-year or more simulation period in order to produce statistical comparisons.

The latter example follows essentially the modeling choices made in connection with the Geological Survey's case study of the Willamette River basin (Shearman, 1976).

\section{SUMMARY}

Sound water-resource planning for the future will rely heavily on hydrologic models as an aid in
TABLE 1.-Example of modeling study planning-factors for modeling choices

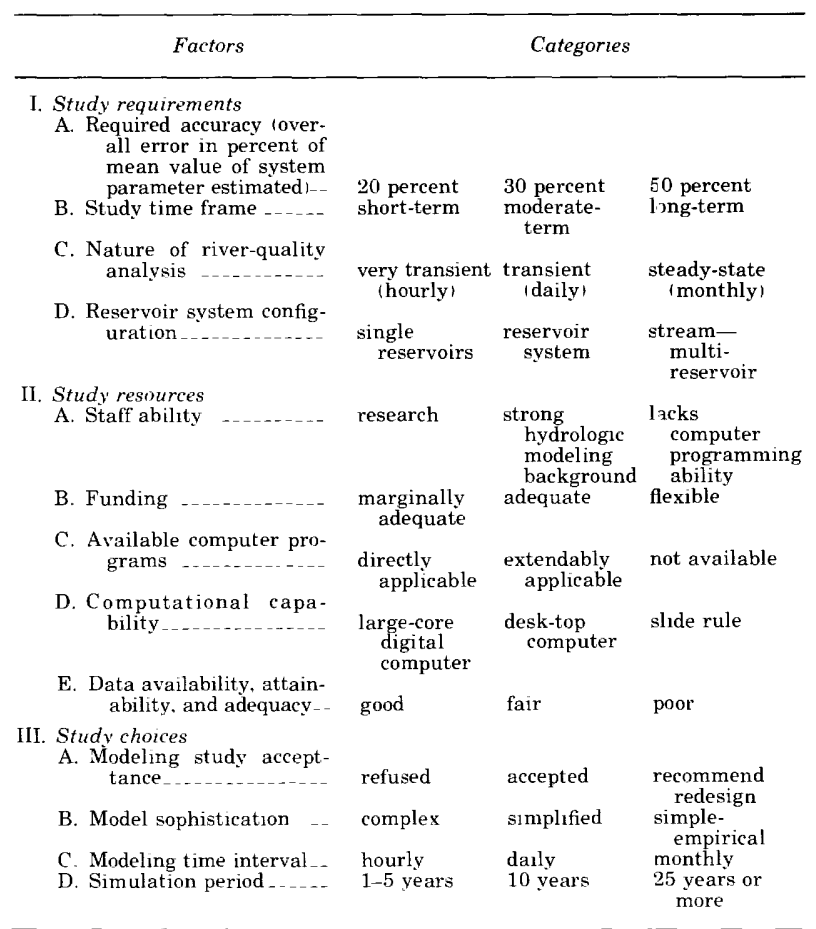

decision-making. Recent water-quality studies by the U.S. Geological Survey, oriented toward the needs for planning, require the use of streamflow and reservoir-release models. This report has presented a review of the major types of such models including streamflow routing models, based on numerical solution of hydraulic laws of f ow and on the linear systems approach, and reservoir-release models based on simulation and on mathematical programming concepts. Data requirements for modeling applications are also discussed. Suggestions are offered on the problems of modeling choices and examples are given. Sperifically a diagrammatic approach which lists the questions and choices connected with a given study is presented. Also presented is a table showing an itemization of the major factors of study requirements, study resources, and study choices. Such tools are intended to assist the streamflow and reservoirrelease modeler in constructing guic'elines for making cost-effective modeling choices. The approach has been used in selecting streamflow and reservoir-release models for a case study in the Willamette River basin, Oreg., but it is also generally applicable to other studies. 


\section{REFERENGES CITED}

Amein, Michael, and Fang, C. S., 1970, Implicit flood routing in natural channels: Am. Soc. Civil Engineers Jour. Hydraulics Div., v. 96, no. HY12, p. 2481-2500.

Anderson, J. A., 1969, Runoff evaluation and streamflow simulation by computer: Portland, Ore., U.S. Army Engineers, North Pacific Div.

Baltzer, R. A., and Lai, Chintu, 1968, Computer simulation of unsteady flows in waterways: Am. Soc. Civil Engineers Jour. Hydraulics Div., v. 94, no. HY4, p. 1083-1117.

Beard, L. R., 1963, Flood control operation of reservoirs: Am. Soc. Civil Engineers Jour. Hydraulics Div., v. 89, no. HY1 p. 1-24.

Becker, Leonard, and Yeh, W. W-G., 1974, Optimization of real time operation of a multiple-reservoir system: Am. Geophys. Union Water Resources Research, v. 10, no. 6, p. 1107-1112.

Contractor, D. N., and Wiggert, J. M., 1972, Numerical studies of unsteady flow in the James River: Blacksburg, Va., Water Resources Research Center, no. VPI-WRRC-BULL 51 .

Eli, R. N., II, Wiggert, J. M., and Contractor, D. N., 1974 Reverse flow routing by the implicit method: Am. Geophys. Union Water Resources Research, v. 10, no. 3, p. 597-600.

Fiering, M. B., and Jackson, B. A., 1971, Synthetic streamflows: Am. Geophys. Union Water Resources Monograph 1, $98 \mathrm{p}$.

Fread, D. L., 1974, Numerical properties of implicit four-point finite difference equations of unsteady flow: Natl. Oceanog. and Atmospheric Adm. Tech. Memo. No. NWS HYDRO$18,39 \mathrm{p}$.

Garrison, J. M., Granju, J. P., and Price, J. T., 1969, Unsteady flow simulation in rivers and reservoirs: Am. Soc. Civil Engineers Jour. Hydraulics Div., v. 95, no. HY5, p. 1559 1576.

Hall, W. A., and Dracup, J. A., 1970, Water resources systems engineering: New York, McGraw Hill, 372 p.

Harley, B. M., 1967, Linear routing in uniform open channels: Cork, Ireland, University College, Master of Sci. thesis.

Hayami, Shoitiro, 1951, On the propogation of flood waves: Research Inst. Bull. No. 1, Kyoto, Japan, Kyoto Univ., $16 \mathrm{p}$.

Henderson, F. M., 1966, Open channel flow: New York, Macmillan Co., $522 \mathrm{p}$.

Hufschmidt, M. M., and Fiering, M. B., 1966, Simulation techniques for design of water resources systems: Cambridge, Mass., Harvard Univ. Press, 212 p.

Keefer, T. N., and McQuivey, R. S., 1974, Multiple linearization flow routing model: Am. Soc. Civil Eng. Jour. Hydraulics Div., v. 100, no. HY7, p. 1031-1046.

Linsley, R. K., Jr., Kohler, M. A., and Paulhus, J. L. H., 1949, Applied hydrology: New York, McGraw-Hill, 689 p.

Moench, A. F., Sauer, V. B., and Jennings, M. E., 1974, Modification of routed streamflow by channel loss and base flow: Am. Geophys. Union Water Resources Research, v. 10, no. 5, p. 963-968.
National Water Commission, 1973, New directions in U.S. water policy-summary, conclusions, and recommendations from the final report of the national water commission: Washington, U.S. Govt. Printing Office, $197 \mathrm{p}$.

Rickert, D. A., and Hines, W. G., 1975, A practical framework for river-quality assessment: U.S. Geo'. Survey Circ. 715-A, $17 \mathrm{p}$.

Roefs, T. G., and Bodin, L. D., 1970, Multireservoir operation studies: Am. Geophys. Union Water Resources Research, v. 6 , no. 2 , p. $410-420$.

Rutter, E. J., and Engstrom, L. R., 1964, Hydrology of flow control, part III, reservoir regulation, in Handbook of applied hydrology: New York, McGraw-Hill, Ven Te Chow, ed., Chap. 25-III, p. 69-97.

Sauer, V. B., 1973, Unit response method of open-channel flow routing: Am. Soc. Civil Engineers Jour. Hydraulics Div., v. 99, no. HY1, p. 179-193.

Schwarz, R. J., and Friedland, Bernard, 1965, Linear systems: New York, McGraw-Hill, 521 p.

Shearman, J. O., 1976, Reservoir-system model for the Willamette River basin, Oregon: U.S. Geo!. Survey Circ. $715-\mathrm{H}, 22 \mathrm{p}$.

Shearman, J. O., and Swisshelm, R. V., Jr., 1973, Derivation of homogeneous streamflow records in the upper Kentucky River basin, southeastern Kentucky: U.S. Geol. Survey open-file rept. $34 \mathrm{p}$.

Showen, C. R., and Stuthmann, N. G., 1973. Index to U.S. Geological Survey computer files containing daily values for water parameters to September 30, 1971-northeast region: U.S. Geol. Survey Water Resources Inv. 25-73, $354 \mathrm{p}$.

Texas Water Development Board, 1972, Economic optimization and simulation techniques for management of regional water resource systems, river basin simulation model, SIMYLD-II program description: Texas Water Devel. Board, $106 \mathrm{p}$.

Tischler, L .F., 1973, Application of simulation techniques to multi-reservoir systems: paper presented at 54th Annual Conference of the Am. Geophys. Union, Washington, D.C., April, 25 p.

U.S. Army Corps of Engineers, 1968, HEC-3, reservoir systems analysis: Hydrol. Eng. Center Users Marial No. 23-53, $86 \mathrm{p}$.

1969, Proceedings of a seminar on reservoir systems analysis, Nov. 4-6, 1969: Hydrol. Eng. Center.

1973a, Finite element hydrodynamic model, in Water quality report, lower Granite lock and dam, Snake River-Washington, Idaho: U.S. Army Er g. Dist., Walla Walla, Wash, app. F, v. 3, 85 p.

$-1973 b$, HEC-1 flood hydrograph package: Hydrol. Eng. Center Users Manual No. 723-010, 185 p.

U.S. Geological Survey, 1973, Water resources data for Oregon-part 1. surface water records: $40 ? \mathrm{p}$.

Williams, J. R., and Hann, R. W., Jr., 1973, HYMO: problemoriented computer language for hydrologic model: U.S. Dept. Agr., Agr. Research Service No. AR?-S-9, 76 p. 

